\title{
Whole body protein metabolism in children with cancer
}

\author{
S E Daley, A D J Pearson, A W Craft, J Kernahan, R A Wyllie, L Price, C Brock, \\ C Hetherington, D Halliday, K Bartlett
}

\begin{abstract}
Whole body protein synthesis and catabolism were measured using the [ring$\left.{ }^{2} \mathbf{H}_{5}\right]$ phenylalanine and $\left[1-{ }^{13} \mathrm{C}\right]$ leucine primed constant infusion technique in 32 paediatric patients with cancer at different stages of treatment. Rates of synthesis (S) and catabolism (C) derived from the [ring- $\left.{ }^{2} \mathbf{H}_{5}\right]$ phenylalanine and $\left[1-{ }^{13} \mathrm{C}\right]$ leucine models were 4.7 (SD 1.3) (S) and 6.0 (1.5) (C) $\mathrm{g} / \mathrm{d} / \mathrm{kg}$, and $5.5(0.8)(\mathrm{S})$ and $6.8(1.2)$ (C) $\mathrm{g} / \mathrm{d} / \mathrm{kg}$, respectively. These results show that these two tracer techniques give similar results in this study population. Comparison of these values with results previously reported for groups of control children using the $\left[\right.$ ring $\left.^{2}{ }^{2} \mathbf{H}_{5}\right]$ phenylalanine model $(S=3.69$ and 3.93; $C=4.09$ and 4.28 $\mathrm{g} / \mathrm{d} / \mathrm{kg})$ and the $\left[1-{ }^{13} \mathrm{C}\right]$ leucine model $(\mathrm{S}=$ 4.32; $C=4.85 \mathrm{~g} / \mathrm{d} / \mathrm{kg}$ ) show that rates of synthesis and catabolism were higher in cancer patients than in controls. Thus whole body protein turnover is increased in children under treatment for cancer. Other indices of metabolism such as plasma amino acids and intermediary metabolites were also measured and showed that, although subjects were in isotopic steady state, there were significant metabolic changes during the course of the primed constant infusions used to measure protein turnover.

(Arch Dis Child 1996;75:273-281)
\end{abstract}

Keywords: cancer, protein turnover, stable isotope.

Cachexia is a complex and extremely variable syndrome characterised by weight loss, anorexia, and negative nitrogen balance and is present in many cancer patients during the course of their disease. ${ }^{1}{ }^{2}$ In children the cachexia is usually a result of the treatment rather than of the cancer itself. Moreover the protein requirements of children during therapy for malignancy are unknown, both at diagnosis when there is a large tumour burden and during treatment when there are the effects of anticancer drugs and infection. The aetiology of cachexia in children with cancer is multifactorial. Inadequate intake arising from anorexia, mucositis, or malabsorption due to the effects of anticancer drugs, and systemic metabolic factors arising from the effects of the malignancy, chemotherapy, or infection are likely to be contributory. However, since malignancies are typically very chemosensitive in children, very soon in treatment there is minimal or no tumour burden and therefore the major effect is of chemotherapy.

It has been known for some years that survival time is closely related to weight loss ${ }^{3-5}$ and that the attendant loss of body protein is associated with increased rates of whole body protein turnover. ${ }^{6-13}$ There have, however, been conflicting reports. ${ }^{14-18}$ The great majority of the literature is concerned with studies of adults with cancer and there are very few studies of children. An exception is two studies by Kien and Camitta, ${ }^{89}$ who, using the single dose ${ }^{15} \mathrm{~N}$-glycine technique, showed increased rates of whole body protein turnover in children with newly diagnosed leukaemia and lymphoma.

Nutritional support to prevent loss of lean body mass is an integral part of treatment in cancer patients, which frequently takes the form of total parenteral nutrition. Improved nutritional status has a number of positive effects, it results in improved tolerance to chemotherapy in certain types of malignancy, ${ }^{1920}$ improved immune competence, ${ }^{21}$ decreased incidence of opportunistic infections, ${ }^{22}$ and improved prognosis. ${ }^{23}{ }^{24}$ However, it is still uncertain how effective total parenteral nutrition is in reducing cachexia, and in particular what effect it has on protein metabolism. ${ }^{25}$ Moreover, approximately $30 \%$ of children with cancer do not respond to this form of nutritional support. ${ }^{26}$ In order to obtain a better understanding of the effect that total parenteral nutrition has on protein metabolism in children it is necessary to make measures of whole body protein turnover.

Several techniques have been devised for the measurement of whole body protein turnover, based on the administration of stable isotopically labelled amino acids and the measurement of enrichment of either the parent amino acid or some metabolite. The most widely used and validated approach is to give $\left[1-{ }^{13} \mathrm{C}\right]$ leucine as a primed constant 
Table 1 Clinical and anthropometric details of patients studied

\begin{tabular}{|c|c|c|c|c|c|c|c|c|c|c|c|}
\hline $\begin{array}{l}\text { Patient } \\
\text { No }\end{array}$ & Sex & $\begin{array}{l}\text { Age } \\
\text { (years) }\end{array}$ & $\begin{array}{l}\text { Weight } \\
(\mathrm{kg})\end{array}$ & $B M I$ & Diagnosis & Treatment & $\begin{array}{l}\text { Stage of } \\
\text { therapy }\end{array}$ & Infection & Catabolic & Dexamethasone & $\begin{array}{l}\text { Enteral } \\
\text { intake }\end{array}$ \\
\hline 1 & $M$ & 16 & 45.0 & 15.8 & OS & OSP-1 & D & - & + & - & ++ \\
\hline 2 & $\mathbf{M}$ & 15 & 51.5 & 17.2 & os & OSP-2 & D & - & - & + & ++ \\
\hline 3 & $M$ & 3 & 16.2 & 15.3 & $\mathbf{N}$ & $\mathrm{RC}$ & D & + & + & - & NG \\
\hline 4 & $\mathrm{~F}$ & 2 & 12.8 & 15.8 & $\mathbf{N}$ & RC & Pre & - & + & - & + \\
\hline 5 & $\mathbf{M}$ & 3 & 18.5 & 17.4 & ALL & UKALL-XI & D & - & - & - & +++ \\
\hline 6 & $\mathrm{~F}$ & 14 & 54.3 & 18.6 & $\mathrm{~N}$ & $\mathrm{~N}-2$ & Post & - & - & - & +++ \\
\hline 7 & M & 7 & 21.9 & 16.6 & STS & NRP & $\mathrm{D}$ & - & - & + & +++ \\
\hline 8 & $M$ & 2 & 15.0 & 15.3 & $\mathbf{N}$ & $\mathrm{RC}$ & D & + & - & - & + \\
\hline 9 & $M$ & 12 & 34.0 & 17.8 & STS & NRP & D & + & - & - & ++ \\
\hline 10 & $\mathrm{~F}$ & 5 & 21.8 & 17.7 & ALL & UKALL-XI & D & + & - & - & ++ \\
\hline 11 & F & 7 & 20.4 & 14.9 & ALL & UKALL-XI & D & - & - & - & +++ \\
\hline 12 & $\mathbf{M}$ & 7 & 23.0 & 15.4 & STS & NRP & Post & - & - & - & +++ \\
\hline 13 & M & 3 & 15.2 & 15.5 & OS & OSPR-2 & D & - & - & - & ++ \\
\hline 14 & M & 4 & 15.8 & 14.6 & ALL & UKALL-XI & D & + & - & - & ++ \\
\hline 15 & $\mathbf{M}$ & 5 & 14.9 & 13.5 & ES & $\mathrm{N}-5$ & Post & - & - & - & +++ \\
\hline 16 & $\mathbf{M}$ & 2 & 12.0 & 14.5 & ALL & UKALL-XI & D & - & - & - & ++ \\
\hline 17 & $\mathbf{F}$ & 16 & 51.8 & 19.5 & A & UGP & Post & - & - & - & +++ \\
\hline 18 & $\mathrm{~F}$ & 4 & 12.3 & 12.3 & $\mathbf{N}$ & $\mathrm{RC}$ & $\mathrm{D}$ & - & + & - & + \\
\hline 19 & $M$ & 7 & 12.0 & 13.7 & $\mathrm{~N}$ & RC & Post & - & - & - & +++ \\
\hline 20 & $F$ & 19 & 66.0 & 24.2 & os & OSPR-2 & $\mathrm{D}$ & - & - & - & + \\
\hline 21 & $\mathbf{M}$ & 17 & 78.4 & 25.3 & os & OSPR-2 & D & - & - & - & ++ \\
\hline 22 & $\mathrm{M}$ & 9 & 33.6 & 16.7 & NHL & $\mathrm{NHP}$ & Pre & - & - & - & + \\
\hline 23 & $\mathbf{M}$ & 18 & 43.5 & 16.0 & $\mathrm{~N}$ & $\mathrm{RC}$ & Pre & - & + & - & ++ \\
\hline 24 & $\mathbf{M}$ & 17 & 75.6 & 24.1 & STS & NRP & D & - & - & - & ++ \\
\hline 25 & $\mathbf{M}$ & 14 & 35.1 & 14.6 & NHL & NHL-904 & $\mathrm{D}$ & - & - & - & ++ \\
\hline 26 & $\mathbf{M}$ & 17 & 58.7 & 18.1 & GCT & NST & $\mathrm{D}$ & + & - & - & ++ \\
\hline 27 & $\mathrm{~F}$ & 8 & 19.4 & 12.3 & OS & OSPR-2 & D & - & + & - & + \\
\hline 28 & $\mathbf{F}$ & 16 & 50.7 & 16.9 & ES & EICESS & D & - & + & + & + \\
\hline 29 & $\mathrm{~F}$ & 12 & 49.3 & 17.7 & OS & OSPR-1 & Pre & - & - & - & ++ \\
\hline 30 & $\mathbf{M}$ & 4 & 15.2 & 16.1 & STS & MMT 1989 & Pre & - & - & - & ++ \\
\hline 31 & $\mathbf{M}$ & 12 & 36.2 & 16.1 & ALL & UKALL-XI & D & - & - & - & ++ \\
\hline 32 & $\mathbf{M}$ & 5 & 21.8 & 17.4 & STS & NRP & Post & - & - & - & +++ \\
\hline 33 & $\mathrm{~F}$ & 7 & 22.3 & 13.2 & STS & NRP & Pre & - & - & - & ++ \\
\hline 34 & $\mathrm{~F}$ & 3 & 17.2 & & ALL & UKALL-XI & $\mathrm{D}$ & - & - & - & +++ \\
\hline 35 & $\mathrm{~F}$ & 12 & 31.6 & 14.5 & STS & NRP & D & + & - & - & + \\
\hline 36 & $\mathbf{M}$ & 12 & 65.0 & 14.9 & OS & OSPR-2 & Pre & - & - & - & ++ \\
\hline
\end{tabular}

$\mathrm{BMI}=$ body mass index; $\mathrm{N}=$ neuroblastoma, $\mathrm{ALL}=$ acute lymphoblastic leukaemia, $\mathrm{OS}=$ osteogenic sarcoma, $\mathrm{STS}=$ soft tissue sarcoma, $\mathrm{NHL}=$ non-Hodgkin's lymphoma, ES = Ewing's sarcoma, A = astrocytoma, GCT = germ cell tumour. UKALL-XI = United Kingdom ALL trial XI, MRCP = Medical Research Council protocol, OSPR-1 or $2=$ osteogenic sarcoma protocol regimen 1 or $2, \mathrm{NRP}=$ Newcastle rhabdomyosarcoma protocol, $\mathrm{MMT}=$ malignant mesenchymal tumour trial, RC = Rapid Cojec, NHP = non-Hodgkin's protocol 902, N-2 or $-5=$ Napoleon-2 or -5 protocol, NHL-904 = UKCCSG NHL-904, NST = non-standard treatment, UGP = UKCCSG - high grade glioma protocol, EICESS = European Intergroup co-operative Ewing's sarcoma study. Stage of therapy: Pre = at diagnosis, before treatment; $D=$ during therapy; Post $=$ after the completion of therapy. Infections: $+=$ infection or recovering from infection at time of study. Catabolic: $+=$ catabolic at time of study. Dexamethasone: $+=$ receiving dexamethasone. Enteral intake: $+=$ minimal; $++=$ moderate; $+++=$ normal; $\mathrm{NG}=$ nasogastric feeding.

infusion and measure the enrichment of its transamination product $\left[1-{ }^{13} \mathrm{C}\right] 2$-oxoisocaproic acid. However in order to determine protein oxidation it is necessary to measure the production of ${ }^{13} \mathrm{CO}_{2}$, which in turn requires the measurement of the rate of $\mathrm{CO}_{2}$ production by means of indirect calorimetry. An alternative technique requires the administration of [ring${ }^{2} \mathrm{H}_{5}$ ] phenylalanine and oxidation is estimated from the measurement of the enrichment of [ring $-{ }^{2} \mathrm{H}_{4}$ ]tyrosine. This avoids the need for indirect calorimetry.

In this study our objectives were first, to assess the feasibility of measuring whole body protein metabolism using the primed constant infusion technique in children at different stages of treatment for malignancy, and second, to compare the $\left[\right.$ ring $^{2} \mathrm{H}_{5}$ ]phenylalanine ${ }^{27}$ and $\left[1-{ }^{13} \mathrm{C}\right]$ leucine ${ }^{28}$ models for measurement of the kinetics of whole body protein turnover.

\section{Methods}

PATIENTS

Thirty six patients with malignancy (23 male, 13 female; mean age 9.3 years, range 2-19 years; mean weight $33.0 \mathrm{~kg}$, range 12.0-78.4 $\mathrm{kg}$ ) were studied. The underlying malignancy varied and included patients with osteogenic sarcoma (8), soft tissue sarcoma-including rhabdosarcoma (8), neuroblastoma (7), acute lymphoblastic leukaemia (7), Ewing's sarcoma (2), non-Hodgkin's lymphoma (2), germ cell tumour (1), and astrocytoma (1). Their treatment was according to national or international protocols. They were studied at different stages of treatment: at diagnosis before treatment was started (7), during treatment (23), and after the completion of treatment (6). Seven of the children investigated during treatment had, or were recovering from, an infection at the time of study. Seven patients were catabolic and losing weight but only one was receiving any supplementary nutrition, by nasogastric feeding, at the time of study. Exclusion criteria for the study were as follows: (1) children receiving total parenteral nutrition, (2) children under the age of 2 years, (3) children without venous access necessary for clinical purposes. Chemotherapy was not given to any child at the time of study; however, three children were receiving dexamethasone. Informed consent was obtained from the parents of these children and the study was approved by the joint University/Newcastle Health $\mathrm{Au}$ thority ethics committee. Clinical and anthropometric details of the patients studied are summarised in table 1.

\section{ISOTOPES}

L- $\left[1-{ }^{13} \mathrm{C}\right]$ leucine $\left(99 \%{ }^{13} \mathrm{C}\right), \mathrm{L}-\left[\right.$ ring $\left.-{ }^{2} \mathrm{H}_{5}\right]$ phenylalanine $\left(98 \%{ }^{2} \mathrm{H}\right)$, L- $\left[\right.$ ring $\left.^{2} \mathrm{H}_{4}\right]$ tyrosine $(98 \%$ $\left.{ }^{2} \mathrm{H}\right)$ and sodium $\left[{ }^{13} \mathrm{C}\right]$ bicarbonate $\left(99 \%{ }^{13} \mathrm{C}\right)$ were obtained from Promochem Limited. Isotopically labelled substrates were infused in a 
solution of normal saline that was shown to be sterile and pyrogen-free.

\section{MEASUREMENTS OF WHOLE BODY PROTEIN} TURNOVER

Rates of whole body protein turnover were assessed in 32 subjects by the [ring$\left.{ }^{2} \mathrm{H}_{5}\right]$ phenylalanine $\mathrm{e}^{27}$ and $\left[1-{ }^{13} \mathrm{C}\right]$ leucine $\mathrm{e}^{28}$ infusion methods. Whole body protein synthesis and catabolism was determined in 32 subjects using the phenylalanine model, and rates of protein synthesis were measured in 19 patients using the leucine model.

\section{PROCEDURE}

Patients were studied as outpatients or inpatients when admitted for clinical purposes to the children's cancer unit, Royal Victoria Infirmary. Patients were fasted overnight before the study and remained so for the duration of the investigation An intravenous cannula was inserted into a vein on the back of one hand for blood collection. Isotopes were infused through a central venous catheter, which was present as part of the normal management of these patients. In some studies a double lumen central venous catheter was used (patients 19-36). In this circumstance the infusion given through one lumen was halted for two minutes before sampling from the second lumen; a validation study comparing simultaneous central and peripheral sampling is described in Results which showed that this length of time was sufficient to avoid contamination of the sampling lumen with infusate and short enough to preclude compromising steady state conditions. After collection of baseline blood and expired air samples, priming bolus doses of [ring ${ }^{2} \mathrm{H}_{5}$ ]phenylalanine $(0.5 \mathrm{mg} / \mathrm{kg})$, [ring$\left.{ }^{2} \mathrm{H}_{4}\right]$ tyrosine $(0.08 \mathrm{mg} / \mathrm{kg}),\left[1-{ }^{13} \mathrm{C}\right]$ leucine $(0.5$ $\mathrm{mg} / \mathrm{kg}$ ), and sodium. $\left[{ }^{13} \mathrm{C}\right]$ bicarbonate $(0.08$ $\mathrm{mg} / \mathrm{kg}$ ) were given, followed by a continuous constant infusion of $\left[\right.$ ring $\left.^{2} \mathrm{H}_{5}\right]$ phenylalanine $(0.5 \mathrm{mg} / \mathrm{h} / \mathrm{kg})$ and $\left[1-{ }^{13} \mathrm{C}\right]$ leucine $(0.5 \mathrm{mg} / \mathrm{h} / \mathrm{kg})$ over a $3 \mathrm{~h}$ period. Blood and expired air samples were collected at $90,120,135,150$, 165 , and 180 minutes after the start of the infusion. Each blood sample was collected into heparinised tubes, immediately centrifuged at $4^{\circ} \mathrm{C}$, and the plasma stored at $-80^{\circ} \mathrm{C}$ until analysis. In the subjects in which leucine oxidation was determined, expired air total $\mathrm{CO}_{2}$ production rate was measured by open circuit indirect calorimetry using a ventilated hood system. ${ }^{29}$

Plasma and whole blood specimens were collected at the beginning and end of each infusion study for the measurement of amino acids and intermediary metabolites respectively.

\section{ANALYSES}

The enrichment of the transamination product of $\left[1-{ }^{13} \mathrm{C}\right]$ leucine, $\left[1-{ }^{13} \mathrm{C}\right] 20 x o i s o c a p r o i c$ acid, was measured rather than leucine because the latter is derived from the transamination of intracellular leucine and thus gives a better measure of the precursor enrichments for both leucine turnover and oxidation. ${ }^{30}$ Plasma 2- oxoisocaproic acid was extracted and converted to its quinoxalinol-trimethylsilyl derivative by the method of Ford et al. ${ }^{31}$ The ${ }^{13} \mathrm{C}$ enrichment was measured by electron-impact gas chromatography-mass spectrometry (Finnigan MAT 1020) using selected ion monitoring. The fragment ions of 2-oxoisocaproic acid measured by this process were $\mathrm{m} / \mathrm{z}$ 232 and 233 for $\left[{ }^{12} \mathrm{C}\right] /\left[{ }^{13} \mathrm{C}\right]$ 2-oxoisocaproic acid. The ${ }^{13} \mathrm{C}$ enrichment of expired carbon dioxide was determined by isotope ratio mass spectrometry (IRMS).

Plasma phenylalanine and tyrosine were extracted and converted to their t-butyldimethylsilyl derivatives as previously described. ${ }^{32}$ The deuterium enrichments of these derivatives were determined by electronimpact gas chromatography-mass spectrometry using selected ion monitoring. The fragment ions measured for both phenylalanine and tyrosine are 57 atomic mass units less than their molecular ions formed by the loss of a single butyl group. Therefore the fragment ions are $\mathrm{m} / \mathrm{z} 336$ and 341 for $\left[{ }^{2} \mathrm{H}_{0}{ }^{2} \mathrm{H}_{5}\right]$ phenylalanine and $\mathrm{m} / \mathrm{z} 466$ and 470 for $\left[{ }^{2} \mathrm{H}_{0}{ }^{2} \mathrm{H}_{4}\right]$ tyrosine.

Plasma amino acid concentrations were determined using a Beckmann 6300 amino acid analyser (System Gold ${ }^{\mathrm{TM}}$ ). Blood intermediary metabolites and non-esterified fatty acids were measured enzymatically using a Cobas bio fast centrifugal analyser as previously described. ${ }^{33}$

\section{CALCULATIONS OF WHOLE BODY PROTEIN}

TURNOVER

Whole body protein turnover was calculated by applying steady state kinetics modified for stable isotope tracers. ${ }^{28}$ In the steady state, amino acid flux for both phenylalanine and leucine $(\mathrm{Q} ; \mu \mathrm{mol} / \mathrm{h} / \mathrm{kg}$ ) was calculated by isotope dilution:

$$
Q=I\left(E_{i} / E_{p}-1\right)
$$

where $I$ is the isotope infusion rate $(\mu \mathrm{mol} / \mathrm{h} / \mathrm{kg})$, $\mathrm{E}_{\mathrm{i}}$ is the enrichment of the labelled amino acid in the infusate (atom \% excess, ape), and $\mathrm{E}_{\mathrm{p}}$ is the enrichment of the labelled amino acid in plasma at isotopic steady state (ape).

The rate of phenylalanine conversion to tyrosine $\left(Q_{p t} ; \mu \mathrm{mol} / \mathrm{h} / \mathrm{kg}\right)$ was determined using equation 2 . This equation is derived as described previously ${ }^{27}$ to allow phenylalanine hydroxylation to be measured without direct measurement of tyrosine flux.

$$
Q_{p t}=\left(P_{t} / P_{p}\right) \cdot Q_{p}{ }^{2} \cdot\left(E_{p} / E_{t}\right)^{-1} \cdot\left(i_{p}+Q_{p}\right)^{-1}
$$

where $P_{\mathfrak{t}} / P_{p}$ is the molar ratio of the fluxes of tyrosine and phenylalanine arising from protein catabolism and a published value of 0.73 is assumed, ${ }^{34} Q_{p}$ is the phenylalanine flux ( $\mu \mathrm{mol} /$ $\mathrm{h} / \mathrm{kg}$ ), $\mathrm{E}_{\mathrm{p}}$ is the enrichment of [ring${ }^{2} \mathrm{H}_{5}$ ]phenylalanine in plasma (ape), $\mathrm{E}_{\mathrm{t}}$ is the enrichment of $\left[\right.$ ring $\left.{ }^{2} \mathrm{H}_{4}\right]$ tyrosine in plasma (ape), and $i_{p}$ the infusion rate of [ring${ }^{2} \mathrm{H}_{5}$ ]phenylalanine $(\mu \mathrm{mol} / \mathrm{h} / \mathrm{kg})$.

Leucine oxidation $(\mathrm{O} ; \mu \mathrm{mol} / \mathrm{h} / \mathrm{kg})$ was determined from measurements of ${ }^{13} \mathrm{CO}_{2}$ enrichment in expired air samples and the $\mathrm{CO}_{2}$ production rate. The rate of ${ }^{13} \mathrm{CO}_{2}$ released by 
Table 2 Plasma amino acid compositions of patients during protein turnover studies

\begin{tabular}{|c|c|c|c|c|c|c|c|c|}
\hline \multirow{2}{*}{ Amino acid } & \multicolumn{3}{|c|}{ Baseline values ( $\mu$ molll) } & \multicolumn{3}{|c|}{ Plateau values ( $\mu \mathrm{mol} / \mathrm{l})$} & \multirow{2}{*}{ Mean diff } & \multirow{2}{*}{ SEM } \\
\hline & Number & Mean & Range & Number & Mean & Range & & \\
\hline Phosphoserine & 23 & 5 & $0-10$ & 23 & 5 & $0-13$ & -0.65 & 0.50 \\
\hline Taurine & 32 & 41 & $14-91$ & 32 & 40 & $16-110$ & 1.72 & 2.00 \\
\hline Aspartate & 32 & 9 & $4-16$ & 32 & 8 & $4-14$ & 0.56 & 0.40 \\
\hline Threonine & 32 & 113 & $61-228$ & 32 & 107 & $46-230$ & 5.50 & 4.19 \\
\hline Serine & 32 & 111 & $54-166$ & 32 & 108 & 53-171 & 3.09 & 4.06 \\
\hline Asparagine & 22 & 20 & $0-60$ & 22 & 27 & $0-107$ & -6.45 & 5.40 \\
\hline Glutamate & 32 & 74 & $39-143$ & 29 & 73 & $27-218$ & 1.90 & 4.48 \\
\hline Glutamine & 32 & 438 & $88-708$ & 32 & 431 & $159-711$ & 6.70 & 11.00 \\
\hline Glycine & 32 & 266 & $124-474$ & 32 & 251 & $116-410$ & 14.75 & 8.07 \\
\hline Alanine & 32 & 259 & $96-494$ & 32 & 214 & $85-493$ & 45.20 & 16.60 \\
\hline Citrulline & 30 & 15 & $0-48$ & 30 & 13 & $0-51$ & 1.17 & 1.60 \\
\hline Valine & 32 & 172 & $78-353$ & 32 & 166 & $82-344$ & 6.19 & 7.58 \\
\hline Cystine & 32 & 41 & $2-190$ & 32 & 43 & 4-145 & -2.25 & 4.19 \\
\hline Methionine & 31 & 17 & $0-35$ & 30 & 17 & $0-41$ & 0.10 & 1.33 \\
\hline Isoleucine & 32 & 47 & $20-92$ & 32 & 46 & $13-108$ & 1.12 & 3.52 \\
\hline Leucine & 32 & 100 & $45-181$ & 32 & 106 & $60-209$ & -6.53 & 5.52 \\
\hline Tyrosine & 32 & 51 & $23-94$ & 32 & 48 & $16-76$ & 3.72 & 2.56 \\
\hline Phenylalanine & 32 & 65 & $23-206$ & 32 & 64 & $23-150$ & 1.03 & 6.18 \\
\hline Ornithine & 31 & 69 & $25-161$ & 31 & 60 & $22-116$ & 8.65 & 4.29 \\
\hline Lysine & 32 & 148 & $69-232$ & 32 & 140 & $62-362$ & 7.75 & 9.27 \\
\hline Histidine & 32 & 90 & $22-189$ & 32 & 91 & $21-224$ & -0.19 & 4.75 \\
\hline Arginine & 30 & 60 & $0-135$ & 30 & 60 & $0-216$ & 0.33 & 5.46 \\
\hline Hydroxyproline & 22 & 26 & $0-94$ & 22 & 26 & $0-132$ & 0.64 & 5.42 \\
\hline Proline & 32 & 160 & $22-285$ & 32 & 156 & $83-465$ & 4.60 & 12.20 \\
\hline
\end{tabular}

Plateau [alanine] < Baseline [alanine] (bold type), $\mathrm{p}=0.009$; all other values not significantly different.

leucine tracer oxidation $(\mu \mathrm{mol} / \mathrm{h} / \mathrm{kg})$ is:

$$
\begin{aligned}
& \mathrm{F}^{13} \mathrm{CO}_{2}=\mathrm{FCO}_{2} \cdot \mathrm{ECO}_{2} \cdot \mathrm{W}^{-1} \cdot(60 \times \\
& 4.6 / 100 \times \mathrm{R} \text { ) }
\end{aligned}
$$

where $\mathrm{FCO}_{2}$ is the $\mathrm{CO}_{2}$ production rate $\left(\mathrm{cm}^{3} /\right.$ min), $\mathrm{E}^{13} \mathrm{CO}_{2}$ is the ${ }^{13} \mathrm{CO}_{2}$ enrichment in expired air at isotopic steady state, and $\mathrm{W}$ is the subject's weight $(\mathrm{kg})$. The constants $60 \mathrm{~min} / \mathrm{h}$ and $44.6 \mu \mathrm{mol} / \mathrm{cm}$ convert $\mathrm{FCO}_{2}$ to $\mu \mathrm{mol} / \mathrm{h}$; the factor 100 changes ape to a fraction; and the factor $\mathrm{R}$ accounts for the fraction of ${ }^{13} \mathrm{CO}_{2}$ released by $\left[1^{13} \mathrm{C}\right]$ leucine oxidation but not released from the body bicarbonate pool into expired air. This has a published value of $0.81^{28}$ but for the purposes of this study was experimentally determined to be 0.75 by means of a bicarbonate recovery study (see Results). The rate of leucine oxidation is:

$$
\mathrm{C}=\mathrm{F}^{13} \mathrm{CO}_{2} \cdot\left(1 / \mathrm{E}_{\mathrm{p}}-1 / \mathrm{E}_{\mathrm{i}}\right) \times 100(4)
$$

In the fasted steady state:

$$
\mathrm{Q}=\mathrm{S}+\mathrm{O}=\mathrm{C}
$$

where $S$ is the loss of the labelled amino acid from the amino acid pool into protein synthesis, $C$ is the entry of the labelled amino acid into the free amino acid pool from protein catabolism, and $\mathrm{O}$ is either phenylalanine hydroxylation $\left(Q_{p t}\right)$ or leucine oxidation $(O)$.

The rates of protein synthesis and catabolism in $\mathrm{g} / \mathrm{d} / \mathrm{kg}$ were calculated by assuming the phenylalanine and leucine content of protein to be 280 and $629 \mu \mathrm{mol} / \mathrm{g}$ protein, respectively. ${ }^{34}$

\section{STATISTICAL ANALYSIS}

Results were analysed by means of the two tailed Student's $t$ test using the Minitab program.

\section{Results}

AMINO ACIDS AND INTERMEDIARY METABOLITES The plasma amino acid composition was determined for each patient before starting the primed constant infusions of stable isotopically labelled substrates ( $-45 \mathrm{~min}$; baseline) and at the end of each infusion ( $+180 \mathrm{~min}$; plateau). The results are summarised in table 2 . There were no statistically significant differences observed between the baseline and plateau values with the exception of alanine which decreased over the course of the infusion by a mean value of $45 \mu \mathrm{mol} / 1(p=0.009)$. The observation that there were no differences in leucine, phenylalanine, or tyrosine concentrations is of particular relevance to the measurement of whole body protein turnover, since this is a necessary condition for the application of steady state kinetics in these turnover models. However, it is clear that there are differences in the concentrations of the major metabolic fuels (table 3 ). There were significant decreases in glucose and alanine and significant increases in NEFA, acetoacetate, and 3-hydroxybutyrate which are to be expected since the turnover studies imposed a further four hours of fasting following the overnight fast.

DETERMINATION OF ${ }^{13} \mathrm{CO}_{2}$ RECOVERY

We measured the whole body protein turnover in children with cancer by two independent methods using either the leucine model or the phenylalanine model. The leucine model involves a reciprocal pool technique in which the enrichment of $\left[1-{ }^{13} \mathrm{C}\right] 2$-oxoisocaproic acid is determined following a primed constant infusion of $\left[1-{ }^{13} \mathrm{C}\right]$ leucine. In this model it is necessary to determine the steady state enrichment of ${ }^{13} \mathrm{CO}_{2}$ in order to calculate protein oxidation. This in turn requires knowledge of the degree of ${ }^{13} \mathrm{CO}_{2}$ 'retention'. The recovery of ${ }^{14} \mathrm{CO}_{2}$ has been shown to be $80-85 \%$ in adults during an infusion of labelled bicarbonate ${ }^{35}$ which is in good agreement with a value of $81 \%$ obtained using ${ }^{13} \mathrm{CO}_{2}{ }^{36}$ However, this has not been validated for the study population in the present investigation. We therefore determined ${ }^{13} \mathrm{CO}_{2}$ recovery as follows. A $3 \mathrm{~h}$ primed constant infusion of $\mathrm{NaH}^{13} \mathrm{CO}_{3}(0.25 \mu \mathrm{mol} / \mathrm{kg} /$ 
Table 3 Blood intermediary metabolites of patients during protein turnover studies

\begin{tabular}{|c|c|c|c|c|c|c|c|c|}
\hline & \multirow{2}{*}{ Number } & \multicolumn{2}{|c|}{ Baseline (mmolll) } & \multicolumn{2}{|c|}{ Plateau (mmolll) } & \multirow{2}{*}{ Mean diff } & \multirow{2}{*}{$S E M$} & \multirow{2}{*}{ p Value } \\
\hline & & Mean & Range & Mean & Range & & & \\
\hline Glucose & 31 & 5.07 & $3.67-7.19$ & 4.56 & $3.17-7.47$ & 0.507 & 0.173 & 0.0064 \\
\hline Lactate & 31 & 0.79 & $0.0-1.71$ & 0.74 & $0.0-2.29$ & 0.047 & 0.072 & 0.52 \\
\hline Pyruvate & 31 & 0.07 & $0.02-0.15$ & 0.07 & $0.02-0.15$ & 0.003 & 0.005 & 0.60 \\
\hline Alanine & 31 & 0.24 & $0.10-0.48$ & 0.20 & $0.08-0.43$ & 0.046 & 0.016 & 0.0078 \\
\hline 3-Hydroxybutyrate & 31 & 0.13 & $0.0-1.32$ & 0.32 & $0.0-2.25$ & -0.190 & 0.057 & 0.0024 \\
\hline Acetoacetate & 31 & 0.12 & $0.0-0.75$ & 0.17 & $0.0-0.89$ & -0.055 & 0.014 & 0.0006 \\
\hline Glycerol & 31 & 0.06 & $0.0-0.24$ & 0.06 & $0.0-0.22$ & -0.001 & 0.004 & 0.74 \\
\hline NEFA & 31 & 0.65 & $0.07-2.02$ & 1.08 & $0.02-2.69$ & -0.430 & 0.100 & 0.0002 \\
\hline
\end{tabular}

min) was performed on four overnight fasted patients and breath samples collected at 120 , $135,150,165$, and 180 min after starting the infusion for the measurement of ${ }^{13} \mathrm{CO}_{2}$ enrichment by IRMS. $\mathrm{CO}_{2}$ production was determined by indirect calorimetry. Patients $32-34$ were studied and a mean recovery of $74.6 \%$ (SD 3.9) was obtained. This value was used for all calculations of rates of protein oxidation.

\section{COMPARISON OF CENTRAL AND PERIPHERAL}

SAMPLING

The conventional technique for primed constant infusions involves administration of the tracer through an antecubital fossa vein, samples being withdrawn from a superficial hand vein in the same or the contralateral arm. Our early studies were hampered by limited access to patients. Venesection was only permitted if required for normal clinical management, for example when patients required renal function assessment. In our early studies tracer was infused through an indwelling single lumen central venous catheter and samples were removed through a peripheral vein. Double lumen catheters were introduced to simplify management and this gave an opportunity to perform primed constant infusions much more conveniently, that is, to infuse through one lumen and sample from the other. However, in our early experiments using this technique it became apparent that timing was crucial. If samples were withdrawn while the infusion was maintained there was variable contamination of the samples by infusate. Conversely if the pump was switched off for too long a period, the measured enrichments declined. Pilot experiments showed that switching off the infusion pump for a period of two minutes was sufficient to avoid contamination (results not shown). However, to demonstrate the robustness of this approach we collected peripheral and central samples in six studies and determined the isotopic enrichments of $\left[1{ }^{13} \mathrm{C}\right] 2$-oxoisocaproic acid, [ring${ }^{2} \mathrm{H}_{5}$ ]phenylalanine and $\left[\right.$ ring $\left.^{2} \mathrm{H}_{4}\right]$ tyrosine. The data are shown in fig 1 . It can be seen that there is no significant difference in measured enrichments and therefore this sampling procedure was used in subsequent patients (patients 19-36).

VALIDATION OF THE PHENYLALANINE-TYROSINE MODEL IN CHILDREN WITH CANCER

The measurement of whole body protein turnover by means of a primed constant infusion of $\left[\right.$ ring $\left.{ }^{2} \mathrm{H}_{5}\right]$ phenylalanine with priming of the tyrosine pool with $\left[\right.$ ring $\left.^{2} \mathrm{H}_{4}\right]$ tyrosine has been validated as a model in normal adults. ${ }^{27} 37$ This model presupposes that phenylalanine is degraded only by hydroxylation to tyrosine and further that this reaction is irreversible. It is assumed that under fasting conditions phenylalanine only enters the plasma pool from the breakdown of protein and only leaves it to protein synthesis or by hydroxylation to tyrosine (oxidation) and thus the phenylalanine flux can be related to whole body protein metabolism. A key assumption made by Thompson et $a l,{ }^{27}$ in their original description of the technique, was that there was a constant relation between phenylalanine and tyrosine rates of flux which they confirmed by making an independent measure of tyrosine turnover in four adult subjects by means of a primed constant infusion of $\left[\right.$ ring- $\left.{ }^{2} \mathrm{H}_{2}\right]$ tyrosine. This assumption was verified in the present study population by the same procedure in three children with cancer. This involved carrying out the standard primed constant infusions as described in Methods above, but with the addition of $\left[\right.$ ring $\left.^{2}{ }^{2} \mathrm{H}_{2}\right]$ tyrosine (0.25 $\mathrm{mg} / \mathrm{h} / \mathrm{kg}$ ). Accordingly in the mass spectrometric analyses, in addition to monitoring the ions for $\left[\right.$ ring $\left.-{ }^{2} \mathrm{H}_{5}\right]$ phenylalanine and [ring${ }^{2} \mathrm{H}_{4}$ ] tyrosine $(\mathrm{m} / \mathrm{z}=336341$ and 466470 respectively), $\mathrm{m} / \mathrm{z} 468$ was also determined. The results obtained are shown in table 4 . It can be seen that there is excellent agreement between the predicted and directly determined rates of flux. Therefore the published assumptions for the calculation of phenylalanine hydroxylation were used throughout.

WHOLE BODY PROTEIN TURNOVER STUDIES

Steady state enrichments (defined as three consecutive values whose coefficient of variation $<10 \%$ ) of plasma $\left[\right.$ ring $\left.^{2}{ }^{2} \mathrm{H}_{5}\right]$ phenylalanine, $\left[1-{ }^{13} \mathrm{C}\right] 2$-oxoisocaproic acid, and [ring-

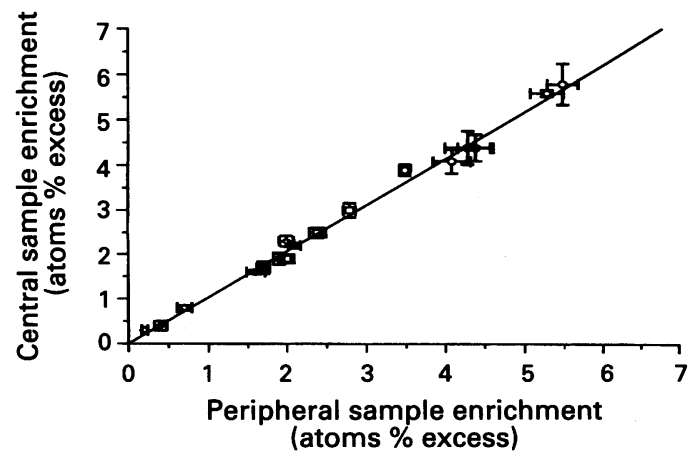

Figure 1 A comparison of the enrichments of phenylalanine [O], 2-oxoisocaproic acid [ㅁ] and tyrosine $[\diamond]$ in central and peripheral blood samples. The error bars indicate $1 S D$. 


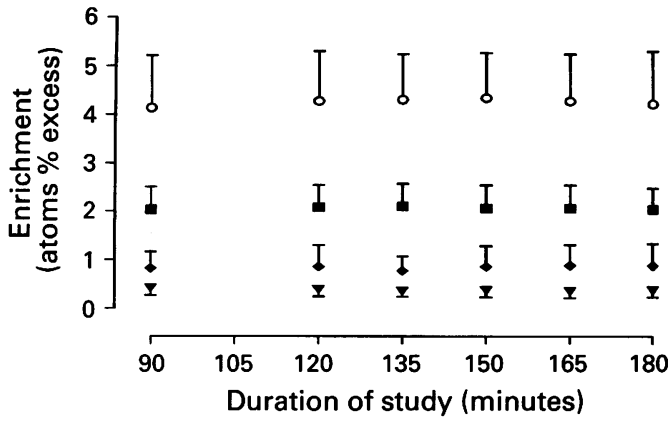

Figure 2 The enrichments of phenylalanine [이 $(n=32)$, 2-oxoisocaproic acid $[\mathbf{\square}](n=32)$, and tyrosine $[\bullet](n=$ 32) in blood and breath $\mathrm{CO}_{2}[\nabla](n=19)$ during a primed constant infusion of $\left[1^{-13} \mathrm{C}\right]$ leucine and [ring- $\left.{ }^{2} \mathrm{H}_{5}\right]$ phenylalanine.

${ }^{2} \mathrm{H}_{4}$ ]tyrosine and breath ${ }^{13} \mathrm{CO}_{2}$ were achieved within $90 \mathrm{~min}$. The mean isotopic enrichments of plasma $\left[\right.$ ring $\left.-{ }^{2} \mathrm{H}_{5}\right]$ phenylalanine, $\left[1{ }^{13} \mathrm{C}\right] 2-$ oxoisocaproic acid, and $\left[\right.$ ring $\left.^{2} \mathrm{H}_{4}\right]$ tyrosine and breath ${ }^{13} \mathrm{CO}_{2}$ over the $180 \mathrm{~min}$ duration of the infusions for the patients studied are shown in fig 2.

Individual values of phenylalanine and leucine flux $(\mu \mathrm{mol} / \mathrm{h} / \mathrm{kg})$, their respective phenylalanine-to-leucine flux ratios $\left(Q_{p} / Q_{1}\right)$, and their rates of oxidation are shown in table 5. The mean value of $0.39(0.08)$ for the phenylalanine-to-leucine flux ratios $\left(Q_{p} / Q_{1}\right)$ found in the present study of children with malignant disease is in close agreement with the value of $0.43(0.03)$ reported by Thompson et al. ${ }^{27}$

Amino acid rates of oxidation and whole body protein turnover values derived from the two amino acid tracer models are presented in table 6. Phenylalanine hydroxylation rates determined in this study were calculated by assuming a tyrosine/phenylalanine flux ratio $\left(P_{t} / P_{p}\right)$ of $0.73 .{ }^{34}$ Whole body protein synthesis and catabolism values are calculated from their respective content in protein. The values derived from the phenylalanine model were 4.7 (1.3) and $6.0(1.5) \mathrm{g}$ protein $/ \mathrm{d} / \mathrm{kg}$ respectively, and the values derived from the leucine model were $5.5(0.8)$ and $6.8(1.2) \mathrm{g}$ protein $/ \mathrm{d} / \mathrm{kg}$, respectively.

\section{Discussion}

Weight loss in cachectic cancer patients appears to be a good prognostic indicator of survival time in a variety of malignancies. ${ }^{3-5}$ In spite of normal protein-energy intake, patients with cancer cachexia lose body protein. Several previous studies have shown this loss of body protein to be associated with increased rates of whole body protein turnover. ${ }^{6-13}$ There are, however, some conflicting reports that have

Table 4 Comparison of calculated and measured rates of phenylalanine hydroxylation and tyrosine flux

\begin{tabular}{|c|c|c|c|c|c|c|}
\hline \multirow{2}{*}{$\begin{array}{l}\text { Patient } \\
\text { No }\end{array}$} & \multicolumn{2}{|c|}{ Protein synthesis $(\mathrm{g} / \mathrm{d} / \mathrm{kg})$} & \multicolumn{2}{|c|}{$\begin{array}{l}\text { Phenylalanine } \\
\text { hydroxylation }(\mu \mathrm{mol} / \mathrm{h} / \mathrm{kg})\end{array}$} & \multicolumn{2}{|c|}{ Tyrosine flux $(\mu \mathrm{mol} / \mathrm{h} / \mathrm{kg}$} \\
\hline & Derived & Measured & Derived & Measured & Derived & Measured \\
\hline 1 & 2.2 & 2.1 & 45.3 & 46.3 & 99.0 & 101.4 \\
\hline 2 & 2.2 & 2.2 & 26.0 & 26.5 & 65.2 & 66.3 \\
\hline 3 & 5.3 & 5.3 & 4.0 & 4.0 & 52.0 & 52.6 \\
\hline
\end{tabular}

shown normal rates of whole body protein turnover in patients with cancer cachexia ${ }^{14}$ and even decreased rates of synthesis and catabolism. ${ }^{15-18}$ In general it has been shown that whole body protein metabolism is increased in patients with malignant disease, and Kien and Camitta ${ }^{8} 9$ showed this to be the case in children with newly diagnosed leukaemia and lymphoma using the single dose ${ }^{15} \mathrm{~N}-$ glycine technique. However, with the exception of these latter reports, the great majority of the studies concerned with the direct measurement of the kinetics of whole body protein metabolism have been of adults. Cachexia in childhood cancer is usually associated with intensive therapy rather than a consequence of cancer per se.

The present study shows that whole body protein metabolism can be successfully measured in children undergoing treatment for cancer by two independent amino acid tracer methods. Phenylalanine and leucine are essential amino acids that can only enter the amino acid pool from the diet and protein catabolism. Phenylalanine and leucine leave the amino acid pool by protein synthesis or by either hydroxylation to tyrosine or oxidation to expired air $\mathrm{CO}_{2}$, respectively. These two models further assume that the free phenylalanine, tyrosine, and leucine pools are homogeneous and well mixed.

We have not studied control groups of age matched children for ethical reasons. In a limited number of reported studies, however, whole body protein metabolism in control groups of children has been reported and the findings are compared with the results of the present study in table 7 . Kien and Camitta ${ }^{89}$ measured whole body protein synthesis and catabolism in control groups of children and also in groups of children with newly diagnosed leukaemia or lymphoma using the single dose ${ }^{15} \mathrm{~N}$-glycine stable isotope technique. This technique has been the subject of much criticism (see for example reference 35 ) and it was for this reason that we used two independent models of protein turnover. These objections not withstanding, Kien and Camitta ${ }^{8}{ }^{9}$ reported that rates of protein synthesis and catabolism were significantly higher in the cancer patients $(S=5.4$ and $5.89 ; C=5.5$ and $6.05 \mathrm{~g} / \mathrm{d} / \mathrm{kg}$ ) compared to healthy controls $(\mathrm{S}=$ 3.6 and $3.71 ; C=3.1$ and $3.05 \mathrm{~g} / \mathrm{d} / \mathrm{kg}$ ). A comparison of the values found for the cancer patients in these two studies ( $S=5.4$ and 5.89; $\mathrm{C}=5.5$ and $6.05 \mathrm{~g} / \mathrm{d} / \mathrm{kg}$ ) with the values obtained in the present study using the phenylalanine $(\mathrm{S}=4.7 ; \mathrm{C}=6.0 \mathrm{~g} / \mathrm{d} / \mathrm{kg})$ and leucine $(\mathrm{S}$ $=5.5 ; \mathrm{C}=6.8 \mathrm{~g} / \mathrm{d} / \mathrm{kg}$ ) models, shows that there is good agreement. However, the values obtained for protein breakdown and synthesis using these two models are significantly different (table 6). The reason for this apparent discrepancy lies in the measurement of the 'reciprocal pool' enrichment of $\left[1-{ }^{13} \mathrm{C}\right] 2-$ oxoisocaproic acid rather than leucine itself. The former is thought to be a more accurate measure of intracellular protein turnover since it more accurately predicts intracellular $\left[1-{ }^{13} \mathrm{C}\right]$ leucine labelling than the direct 
Table 5 Rates of phenylalanine and leucine flux

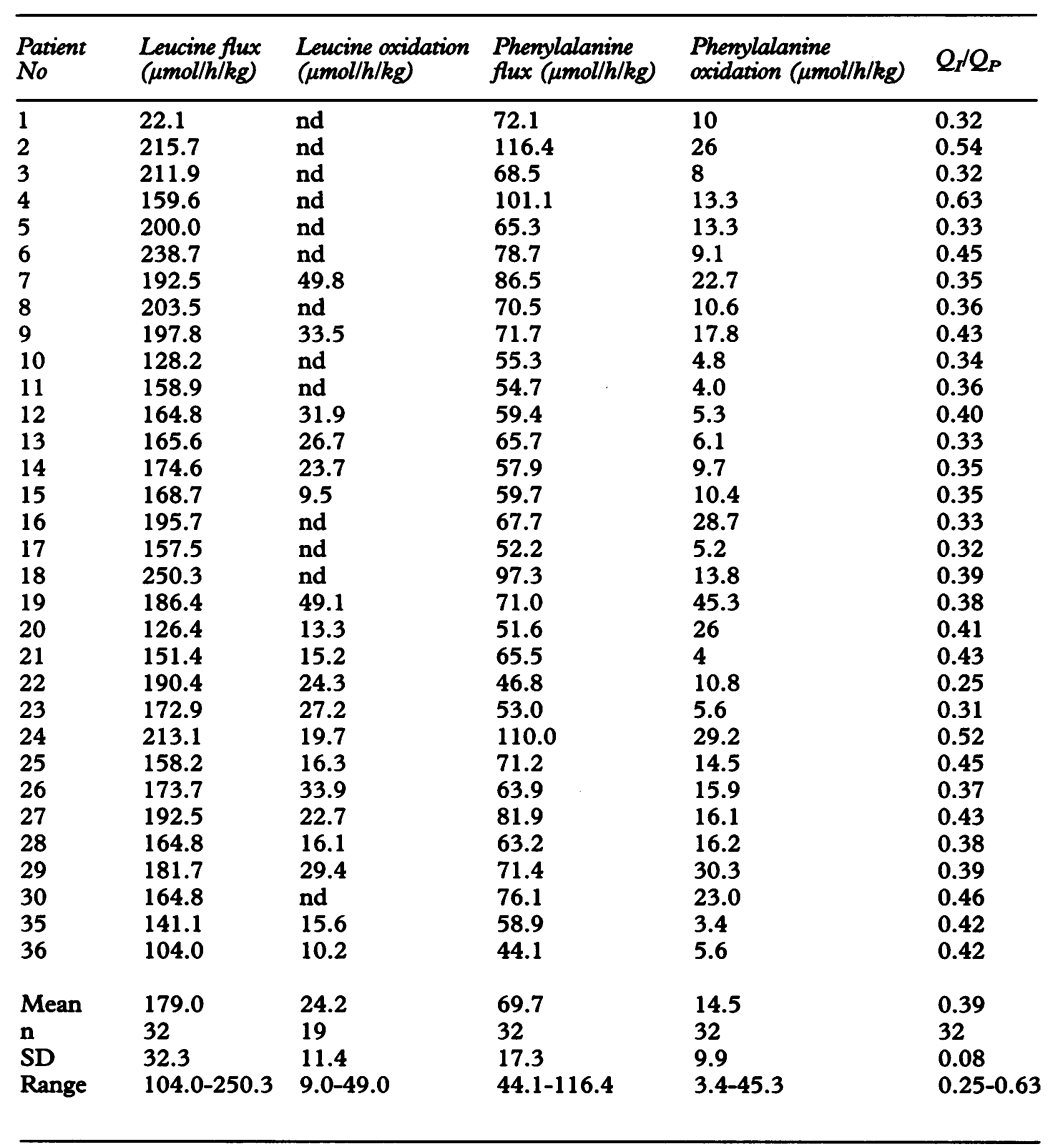

Table 6 Rates of whole body protein synthesis, catabolism and oxidation determined by means of the leucine and phenylalanine models

\begin{tabular}{|c|c|c|c|c|c|c|}
\hline \multirow{2}{*}{$\begin{array}{l}\text { Patient } \\
\text { No }\end{array}$} & \multicolumn{2}{|c|}{ Protein breakdown (g/d/kg) } & \multicolumn{2}{|c|}{ Protein synthesis (g/d/kg) } & \multicolumn{2}{|c|}{ Protein oxidation (g/d/kg) } \\
\hline & Leucine & Phenylalanine & Leucine & Phenylalanine & Leucine & Phenylalanine \\
\hline 1 & 8.6 & 6.2 & nd & 5.3 & nd & 0.9 \\
\hline 2 & 8.2 & 10.0 & nd & 7.7 & nd & 2.3 \\
\hline 3 & 8.1 & 5.9 & nd & 5.2 & nd & 0.7 \\
\hline 4 & 6.1 & 8.7 & nd & 7.5 & nd & 1.2 \\
\hline 5 & 7.6 & 5.6 & nd & 4.5 & nd & 1.1 \\
\hline 6 & 9.1 & 6.7 & nd & 6.0 & nd & 0.7 \\
\hline 7 & 7.3 & 7.4 & 5.4 & 5.5 & 1.9 & 1.9 \\
\hline 8 & 7.8 & 6.0 & nd & 5.1 & nd & 0.9 \\
\hline 9 & 7.5 & 6.1 & 6.3 & 4.6 & 1.2 & 1.5 \\
\hline 10 & 4.9 & 4.7 & nd & 4.3 & nd & 0.4 \\
\hline 11 & 6.1 & 4.7 & nd & 4.3 & nd & 0.4 \\
\hline 12 & 6.3 & 5.1 & 5.1 & 4.6 & 1.2 & 0.5 \\
\hline 13 & 6.3 & 5.6 & nd & 5.1 & nd & 0.5 \\
\hline 14 & 6.7 & 5.0 & 5.6 & 4.1 & 1.1 & 0.9 \\
\hline 15 & 6.4 & 5.1 & 5.5 & 4.2 & 0.9 & 0.9 \\
\hline 16 & 7.5 & 5.8 & nd & 3.3 & nd & 2.5 \\
\hline 17 & 6.0 & 4.5 & 5.6 & 4.0 & 0.4 & 0.5 \\
\hline 18 & 9.6 & 8.3 & nd & 5.7 & nd & 2.6 \\
\hline 19 & 7.1 & 6.1 & 5.2 & 2.2 & 1.9 & 3.9 \\
\hline 20 & 4.8 & 4.4 & 4.3 & 2.2 & 0.5 & 2.2 \\
\hline 21 & 5.8 & 5.6 & 5.2 & 5.3 & 0.6 & 0.3 \\
\hline 22 & 7.3 & 4.0 & 6.3 & 3.1 & 1.0 & 0.9 \\
\hline 23 & 6.6 & 4.5 & 5.6 & 4.1 & 1.0 & 0.4 \\
\hline 24 & 8.1 & 9.4 & 7.4 & 6.9 & 0.7 & 2.5 \\
\hline 25 & 6.0 & 6.1 & 5.4 & 4.9 & 0.6 & 1.2 \\
\hline 26 & 6.6 & 5.5 & 5.3 & 4.1 & 1.3 & 1.4 \\
\hline 27 & 7.3 & 7.0 & 6.5 & 5.6 & 0.8 & 1.4 \\
\hline 28 & 6.3 & 5.4 & 5.7 & 4.0 & 0.6 & 1.4 \\
\hline 29 & 6.9 & 6.1 & 5.8 & 3.5 & 1.1 & 2.6 \\
\hline 30 & 6.3 & 6.5 & nd & 4.6 & nd & 1.9 \\
\hline 35 & 5.4 & 5.1 & 4.9 & 4.8 & 0.6 & 0.3 \\
\hline 36 & 4.0 & 3.8 & 3.6 & 3.3 & 0.4 & 0.5 \\
\hline Mean & $6.8^{\star}$ & & $5.5^{\star}$ & & & 1.3 \\
\hline & 32 & 32 & & 32 & 19 & 32 \\
\hline SD & 1.2 & 1.5 & 0.8 & 1.3 & 0.4 & 0.9 \\
\hline Range & $4.0-9.6$ & $3.8-10.0$ & $3.6-7.4$ & $2.2-7.7$ & $0.4-1.9$ & $0.3-3.9$ \\
\hline
\end{tabular}

nd = not determined; $*$ leucine value significantly higher than phenylalanine value, $p<0.0005$. measurement of plasma $\left[1-{ }^{13} \mathrm{C}\right]$ leucine enrichment. Clearly, the corresponding situation does not arise for the phenylalanine model because phenylalanine does not undergo transamination during the course of its degradation but rather is oxidised to tyrosine.

In order to determine protein synthesis by means of the leucine model it is necessary to measure the enrichment of breath ${ }^{13} \mathrm{CO}_{2}$ to measure leucine oxidation. This in turn requires measurement of $\mathrm{CO}_{2}$ production. Several children were unwilling to undergo indirect calorimetry and found the ventilated hood procedure frightening. It was for this reason, together with the inherent inaccuracies of $\mathrm{CO}_{2}$ production and the questions relating to ${ }^{13} \mathrm{CO}_{2}$ retention, that the phenylalanine model was investigated in this study. In this model it is not necessary to collect breath $\mathrm{CO}_{2}$, and degradation (oxidation) of phenylalanine is determined by measurement of [ring${ }^{2} \mathrm{H}_{4}$ ] tyrosine enrichment. This approach has its own assumptions and technical drawbacks. For example, the concentration and enrichment of tyrosine are both lower than the concentration and enrichment of phenylalanine (table 2 and fig 2; tyrosine concentration $=48$ (12) $\mu \mathrm{mol} / 1$, phenylalanine concentration $=64(29) \mu \mathrm{mol} / 1$, tyrosine enrichment $=0.86(0.43)$ ape, phenylalanine $4.27(0.98)$ ape) and therefore the measurement of $\left[\right.$ ring $\left.-{ }^{2} \mathrm{H}_{4}\right]$ tyrosine enrichment is inherently less precise. An assumption implicit in the phenylalanine model is that the ratio of phenylalanine and tyrosine fluxes is constant and has a value of 0.73 . This was checked in three patients by making an independent measurement of tyrosine flux by means of a concurrent primed constant infusion of $\left[\right.$ ring $\left.-{ }^{2} \mathrm{H}_{2}\right]$ tyrosine. The results showed close agreement between the measured and predicted estimates of tyrosine flux. A similar close agreement between measured and predicted estimates of tyrosine flux has been reported in a study of preterm neonates suffering from respiratory distress syndrome. ${ }^{38}$

It is a necessary condition for the measurement of whole body protein turnover by means of primed constant infusion that steady state conditions prevail with respect to isotopic enrichment and the concentrations of the tracers. We show this to be the case in our study population (fig 2, table 2). However, it is clear that during the course of infusions there are significant changes in glucose, NEFA, ketone bodies, and alanine as the overnight fast is continued for the duration of the infusions. These changes are the inevitable consequences of studies carried out under fasting conditions and would be observed in normal control individuals.

In studies reported by Thompson et al 2739 the kinetics of whole body protein turnover were measured in control groups of children using the same phenylalanine and leucine tracer techniques that have been employed in this study. As shown in table 7 the values for protein synthesis and catabolism measured using the $\left[\right.$ ring $\left.-{ }^{2} \mathrm{H}_{5}\right]$ phenylalanine method $(\mathrm{S}=$ 3.7 and $3.9 ; C=4.1$ and $4.3 \mathrm{~g} / \mathrm{d} / \mathrm{kg}$ ) and $\left[1^{13} \mathrm{C}\right]$ leucine method $(\mathrm{S}=4.3 ; \mathrm{C}=4.8 \mathrm{~g} / \mathrm{d} / \mathrm{kg})$ 
Table 7 Rates of whole body protein synthesis and catabolism in children. Values are mean (SD)

\begin{tabular}{lllll}
\hline Method & Group & Synthesis $(\mathrm{g} / \mathrm{d} / \mathrm{kg})$ & Catabolism $(\mathrm{g} / \mathrm{d} / \mathrm{kg})$ & Reference \\
\hline Glycine & Control & $3.6(0.90)$ & $3.1(1.1)$ & 27 \\
& Cancer & $5.4(1.50)$ & $5.5(1.8)$ & \\
Glycine & Control & $3.71(0.80)$ & $3.05(1.06)$ & 28 \\
& Cancer & $5.89(2.25)$ & $6.05(2.24)$ & 18 \\
Phenylalanine & Control & $3.69(0.50)$ & $4.09(0.50)$ & 39 \\
Phenylalanine & Control & $3.93(0.50)$ & $4.28(0.52)$ & \\
Leucine & Control & $4.32(0.74)$ & $4.85(0.57)$ & Present study \\
Phenylalanine & Cancer & $4.7(1.3)$ & $6.0(1.5)$ & \\
Leucine & Cancer & $5.5(0.8)$ & $6.8(1.2)$ & \\
\hline
\end{tabular}

are lower than the values found in the present study $(\mathrm{S}=4.7$ and $5.5 \mathrm{~g} / \mathrm{d} / \mathrm{kg}$, respectively; $\mathrm{C}=$ 6.0 and $6.8 \mathrm{~g} / \mathrm{d} / \mathrm{kg}$ respectively) in children with cancer. Moreover their values for control children are in good agreement with the control values obtained by Kien and Camitta. ${ }^{89} 9$ Several recent studies of whole body protein turnover using both the leucine and phenylalanine models have appeared. ${ }^{41-43}$ Although these studies were of adult populations in very different clinical settings such as liver cirrhosis, ${ }^{41}$ type I diabetes, ${ }^{42}$ and hypercortisolaemia, ${ }^{43}$ it is of interest that the control values reported show both remarkable consistency and the same relation between whole body protein turnover estimated from the leucine (reciprocal pool) and phenylalanine models $(\mathrm{C}=4.1,4.8,3.2 \mathrm{~g} / \mathrm{d} / \mathrm{kg}$ and $\mathrm{C}=3.2,3.9$, $3.2 \mathrm{~g} / \mathrm{d} / \mathrm{kg}$, respectively), a finding which was also documented by the group which originally described the technique. ${ }^{27} 37$

Taken as a whole the data from the four studies summarised in table 7 and our own results show convincingly that whole body protein synthesis and catabolism are increased in children with cancer compared to control groups of children. It is therefore important to evaluate critically the nutritional support given to these patients, particular during periods of intensive therapy. In this study we have shown that the techniques for the measurement of whole body protein turnover are valid for the study of children with cancer and this provides the basis for an examination of the pathophysiology of nutritional problems in children with malignancy and the efficacy of different interventions.

The financial support of the North of England Children's Cancer Research Fund and the Leukaemia Research Fund is gratefully acknowledged.

1 Kern KA, Norton JA. Cancer cachexia. Fournal of Parenteral and Enteral Nutrition 1988;12:286-98.

2 Belghiti J, Longonnet F, Bourstyn E, Fekete F. Surgical implications of malnutrition and immunodeficiency in patients with carcinoma of the oesophagus. Brf Surg 1983; 70:339-41.

3 Dewys WD, Begg C, Lavin PT, et al. Prognostic effect of weight loss prior to chemotherapy in cancer patients. $A m \mathcal{F}$ Med 1980;69:491-7.

4 Fein R, Kelsen DP, Geller N, et al. Adenocarcinoma of the oesophagus and gastroesophageal junction: prognostic factors and results of therapy. Cancer 1985;56:2512-8.

5 Hickman DM, Miller RA, Rambeau JL. Serum albumin and body weight as predictors of post-operative course in colorectal cancer. Fournal of Parenteral and Enteral Nutrition 1980;4:314-6.

6 Fearon KCH, Hansell DT, Preston T, et al. Influence of whole body protein turnover rate on resting energy expenditure in patients with cancer. Cancer Res 1988;48: 2590-5.

7 Heber D, Chlebowski RT, Ishibashi DE, Herrold JN, Block $\mathrm{JB}$. Abnormalities in glucose and protein metabolism in noncachectic lung cancer patients. Cancer Res 1982;42: 4815-9.
8 Kien CL, Camitta BM. Increased whole body protein turnover in sick children with newly diagnosed leukaemia or lymphoma. Cancer Res 1983;43:5586-92.

9 Kien CL, Camitta BM. Close association of accelerated rates of whole body protein turnover (synthesis and catabolism) and energy expenditure in children with newly diagnosed acute lymphatic leukaemia. fournal of Parenteral diagnosed acute lymphatic leukaemia.

10 Melville S, McNurlan MA, Calder AG, Garlick PJ. Increased protein turnover despite normal energy metabolism and responses to feeding in patients with lung cancer. Cancer Res 1990;50:1125-31.

11 Carmichael MJ, Clague MB, Keir MJ, Johnston IDA. Whole body protein turnover, synthesis and breakdown in patients with colorectal carcinoma. Br ₹ Surg 1980;67:736-9.

12 Jeevanandan $M$, Lowry SF, Horowitz GD, Brennan MF Cancer cachexia and protein metabolism. Lancet 1984; 1423-6.

13 Ward HC, Johnson AW, Halliday D, Sim AJW. Protein metabolism in patients with disseminated maligancy in the metabolism in patients with disseminated maligancy in the postoperative period. $₹$ Surg 1985;79:983-6.

14 Norton JA, Stein TP, Brennan MF. Whole body protein synthesis and turnover in normal man and malnourished synthesis and turnover in normal man and malnourished
patients with and without known cancer. Ann Surg patients with and

15 Hermann VM, Garnick MB, Moore FD, Wilmore DW. Effect of cytotoxic agents on protein kinetic in patients with metastatic cancer. Surgery 1981;90:381-7.

16 Emery PW, Edwards RHT, Rennie MJ, Souhami RL, Halliday $D$. Protein synthesis in muscle measured in vivo in cachectic patients with cancer. $B M \mathcal{F} 1984 ; 289: 584-6$.

17 Glass RE, Fern EB, Garlick PJ. Whole-body protein turnover before and after resection of colorectal tumours. Clin Sci 1983;64:101-8.

18 Harrison RA, Lewin MR, Halliday D, Clark CG. Leucine kinetics in surgical patients. II. A study of the effect of malignant disease and tumour burden. $f$ Surg 1989;76: maligna

19 Rickard KA, Loghmani ES, Grosfeld JL. Short and long term effectiveness of enteral and parenteral nutrition in reversing or preventing protein-energy malnutrition in advanced neuroblastoma. Cancer 1985;56:2881-97.

20 Hays DM, Merritt RJ, Ashley J, White L, Siegel SE. Effect of total parenteral nutrition on marrow recovery during induction therapy for acute non-lymphocytic leukaemia in childhood. Med Pediatr Oncol 1983;11:134-40.

21 Ramirez I, Van Eys J, Carr D. Immunologic evaluation in th nutritional assessment of children with cancer. Am $\mathcal{f}$ Clin Nutr 1985;41:1314-21

22 Van Eys J, Copeland EM, Cangir A, et al. A clinical trial of hyperalimentation in children with metastatic maligancies. Med Pediatr Oncol 1980;8:63-73.

23 Donaldson SS, Wesley MN, DeWys WD, Suskind RM, Jaffe $\mathrm{N}$, Van Eys J. A study of the nutritional status of paediatric cancer patients. $A m \Im$ Dis Child 1981;135:1107-12.

24 Van Eys J. Effect of nutritional status on response to therapy. Cancer Res (suppl) 1982;42:747-53s.

25 Zoltkin SH, Stallings VA, Pencharz PB. Total parenteral nutrition in children. Pediatr Clin North Am 1986;32:381400.

26 Mauer AM, Burgess JB, Donaldson SS, et al. Special nutritional needs of children with malignancies: a review. fournal of Parenteral and Enteral Nutrition 1990;14:315-24.

27 Thompson GN, Pacy PJ, Merritt H, et al. Rapid measurement of whole body and forearm protein turnover using a phenylalanine model. Am $\mathcal{F}$ Physiol 1989;256:E6319.

28 Matthews DE, Motil KJ, Rohrbaugh DK, Burke JF, Young VR, Bier DM. Measurement of leucine metabolism in man from a primed, continuous infusion of $\mathrm{L}\left[1-{ }^{13} \mathrm{C}\right]$ leucine. $A m$ f Physiol 1980;238:E473-9.

29 Garrow JS, Webster JD. A computer-controlled indirec calorimeter for the measurement of energy expenditure in one or two studies simultaneously. Hum Nutr Clin Nutr 1986;40:315-21.

30 Schwenk WF, Beaufrere B, Haymond MW. Use of reciprocal pool specific activities to model leucine metabolism in humans. Am ₹ Physiol 1985;249:E646-50.

31 Ford GC, Cheng KN, Halliday D. Analysis of (1$\left.{ }^{13} \mathrm{C}\right)$ leucine and $\left({ }^{13} \mathrm{C}\right) \mathrm{KIC}$ in plasma by capillary gas chromatography/mass spectrometry in protein turnover chromatography/mass spectrometry in protein
studies. Biomed Mass Spectrom 1985;12:432-6.

32 Schwenk WF, Berg PJ, Beaufrere B, Miles JM, Haymond MW. Use of $t$-butyldimethylsilylation in the gas chromatographic/mass spectrometric analysis of physiologic compounds found in plasma using electron-impact ionisation. Anal Biochem 1984;141:101-9.

33 Bartlett K, Bhuiyan AKMJ, Butler PC, Alberti KGMM Human forearm differences of carnitine, short-chain acyl-carnitine and long-chain acylcarnitine. Clin Sci 1989;77:413-6.

34 Munro HN, Fleck A. Analysis of tissues and body fluids for nitrogenous constituents. In: Munro HM, ed. Mammalian protein metabolism. Vol 3. New York: Academic Press, 1969: 423-525.

35 Allsop JR, Wolfe RR, Burke JF. Tracer priming the bicarbonate pool. F Appl Physiol 1978;45:137-9.

36 Fuller NJ, Murgatroyd PR, Elia $\mathrm{M}$. The recovery of $\mathrm{CO}_{2}$ during a 36 hour infusion of bicarbonate in man. Proc Nutr Soc 1990;49:198A.

37 Pacy PI, Thompson GN, Halliday D. Measurement of whole body protein turnover in insulin-dependent (type $\mathrm{I}$ ) diabetic patients during insulin withdrawal and infusion.
Clin Sci 1991;80:345-52. 
38 Shortland GJ, Walter JH, Fleming PJ, Halliday D. Phenylalanine kinetics in sick preterm neonates with respiratory distress syndrome. Pediatr Res 1994;36:713-9.

39 Thompson GN, Bresson JL, Pacy PJ, et al. Protein and leucine metabolism in maple syrup urine disease. Am $\mathcal{F}$ Physio 1990;258:E654-60.

40 Thompson GN, Pacy PJ, Watts RWE, Halliday D. Protein drome. Pediatr Res 1990;28:240-6.
41 Tessari $P$, Inchiostro $S$, Barazzoni $R$, et al. Fasting and postprandial phenylalanine and leucine kinetics in liver cirrhosis. Am $\mathcal{F}$ Physiol 1994;267:E140-9.

42 Nair SK, Ford GC, Ekberg K, Fernqvist-Forbes E, Wahren J. Protein dynamics in whole body and in splanchnic and leg tissues in type I diabetic patients. $\mathcal{F}$ Clin Invest 1995:95:2926-37.

43 Darmaun D, Matthews DE, Bier DM. Physiological hypercortisolaemia increases proteolysis, glutamine and alanine production. Am $\mathcal{F}$ Physiol 1988;255:E366-73. 